\title{
Epiphany
}

Epiphany: Vol. 6, No. 2, 2013

ISSN 1840-3719

\section{Figural Representation in the Arabic Calligraphy}

Meliha Teparić"

\begin{abstract}
A deep analysis of calligraphic works show deep meaning behind each letter. The most important thing when analyzing such calligraphic works is deep symbolism that each letter carries within itself. A combination of calligraphic letters always show a symbolic message. Thus, vision enacted in calligraphic works invites the viewer towards reflection and contemplation. It is hard to determine what is more appealing an image or the text. In reality there is an equal emphasis on the text and form. Both complement each other as there is always harmonious balance between the two poles of diversity, male and female, matter and spirit and exoteric and esoteric. Yet, it is possible to read the image and to understand diverse messages and visual impressions. Therefore, the main objective of this paper is to illustrate the scope of Arabic calligraphy by focusing on Arabic letters and their use in presenting various artistic figures.
\end{abstract}

Keywords: Arabic Calligraphy, Calligrams and Symbolism

\footnotetext{
Corresponding author: Meliha Teparić; Assist. Prof. International University of Sarajevo; e-mail: mteparic@ius.edu.ba
} 


\section{The Origin of the Arabic Calligraphy}

The Islamic art is not characterized with animal and human figures. However, such artistic expressions have often been included in the miniature paintings, the arts of plastics and in the art of calligraphy. Rare using of the figurative art in Islam was partly due to the prohibition of presenting humans and animals in any kind of painting and sculpture. However, the prohibition of presenting characters among Muslim artists was not always absolutely followed. It is important to mention that in Islam, as well as in Islamic art, there is a clear reflection of Islamic spirituality, God cannot be represented in any physical form. The Holy Qur'an did not ban presenting characters literally, but it is clearly indicated that the faithful themselves should not make and worship idols. Human beings cannot show in any way God's character, power and beauty. Then, due to the necessary precaution that people would not be misled towards idolatry, making the portraiture of Muahmmad (pbuh) was also prohibited. Actually, the religion of Islam is greatly God centered religion and the Prophet Muhammad (pbuh) is but the Messenger of God. Therefore, Muslims are discouraged to turn their faces towards any figure including the figure of the Prophet (pbuh). Then, due to the fears of creating a cult of man making the portraits of the Prophet was prohibited in the very beginning of the emergence of the religion of Islam (Mehinagić, 1973, 27-36; Grabar and Natif, 2003, p. 26). Moreover, even when the Prophet Muhammad (pbuh) was presented in an individual drawings and miniatures describing events from his life, his character in the form of his body and face has never been painted. From the descriptions of the Prophet, by the prophet's companions, it can be concluded that they all saw and experienced Prophet differently. Therefore, for the Muslim community Prophet's experience, sayings and lessons are much more important than his physical features.

Prohibition of presenting the characters is mostly related to the sculptural arts because in the pre-Islamic period, idolatry was developed, and through idolatry, the sculptural art flourished. According to Burckhardt (1985) and King (1985) when the Muslims liberated Mecca, the Prophet ordered the destruction of all statues and idols, which pagan Arabs set up in the courtyard of the Ka'aba, and then he entered the shrine. The walls of the shrine were ornamented by the Byzantine painter, and among the paintings was the display of the Prophet Abraham throwing arrows for divination and the painting of Virgin and Child. The Prophet covered two images with his hands and ordered their removal. The Prophet Muhammad (pbuh) probably did this out of respect for selected and 
honorable people, but not as a sign of approval of painting figures as religious relics, which is contrary to the faith which he was propagating. It seems that Muslim artists realized that painting as a creative act, could be considered as undesirable but not strictly forbidden. However, anything in the Islamic art that could in any way promote idolatry is literally forbidden and Muslims have the consensus about such kind of arts. This could be the reason of conscious avoidance of naturalism and realism in the Islamic art. However, even among today's Muslim artists natural and realistic arts are widely accepted because the art is no longer solely in the service of religion.

\section{The Conception of Arabic Calligraphy}

Presenting characters is consciously avoided in prayer spaces, because the representations of figures in Islamic shrines and mosques have no meaningful or functional purpose. According to Islamic teachings, everything is directed towards the confirmation of the Unity of God, His glory and greatness. Therefore, in so-called sacred art there is no room for the secular art. Usually stylized characters and figures, both human and animal, can be found at ornamented facades or miniature painting in secular art. Then, besides the character presence everything is reduced to the two-dimensionality. In this regard, it would be significant to point out that there is a difference between the sacred arts, traditional arts and religious art (Nasr, 2006, pp. 175-185; Elwazani, n.y., pp. 478-485). Therefore, some works may include religious theme, but it does not necessarily mean that they represent the sacred art. The fundamental concept of the traditional art is based on the principle of Divine Originality. For example, the sacred art of Islam is calligraphic writing of the Holy Qur'an. This type of arts has been widely-discussed by Rene Guenon, Titus Burckhardt and Seyyed Hossein Nasr.

Any form of the artistic representation aims at presenting characters and figures in a way as they resemble each other. Perhaps, such resemblance and realistic representation was derived from the Islamic law which is based on the doctrine of the equality of all people before God. However, such figures are not man-centered and they are not made for the purpose of worship. Representing the characters in Islamic art was derived from the elitist artistic circles because they originally come from the needs of scientific books, then, as illustrations for stories, traditions, and historical events. Burckhardt (2007) argued "it means that every artistic creation must be treated in accordance with the laws and regulations of its domain 
of existence" (p. 130). Such treatment of representational art in Islam was based on certain kind of hidden spirituality, consciously avoiding closer look at the actual and the illusionary material dimension of arts. This was not the result of lack of neither creativity, as often perceived nor inability to naturalize figure. This was the reason why Islamic painting paid less attention to perspective and three-dimensionality. However, it is not possible to overestimate the fact that miniature painting in the Islamic arts partially lost its spirit and experienced decadence when the artistic perspective was introduced in Islamic civilization as a result of European influence.

According to Islamic artists the artistic conception of threedimensionality illustrates humane life that is integrative part of the divine creation. In fact, it seems that the three-dimension is a fundamental problem of banning characters in Islam. Although the statues of the preIslamic Arabs and other idolatrous nations were three-dimensional, ban was based on the number of the Qur'anic verses and the traditions of the Prophet (pbuh). Therefore, this is another example of less significance of the material dimension of arts in comparison to the spiritual and esoteric dimensions. In part, because of this, Islamic art turned to the Arabic calligraphy and found fertile ground for various kinds of the development. Islamic calligraphy was excellent source of inspiration for the Muslim artists because the calligraphic art was directly based on the Holy Qur'an. According to Burckhardt's (2007) interpretation, the first thing that God created was light, and from one part of that light $\mathrm{He}$ created a pen, and the pen was ordered to write what will happen in the future - Lewha-i-Mahfuz (Plate Closely Guarded). Therefore, Nasr (2005) holds that "the original point and the first drop of the Divine pen was beginning of sacred calligraphy, and so the calligraphy began the plastic arts." Nasr (2007) also argued that according to the Islamic philosopher Ibn Sina "the first element ('unsur) in the world was in principio point which, under the action of Nature, was laid out in a line, plane, and finally a three-dimensional body (jism)." In this regard, the basic principle of calligraphic art is a dot or a line that would eventually result in a letter.

Certainly the historical context of origin of calligraphic art in Islamic civilization had significant roots in pre-Islamic era. Overall, throughout the Near East, abstract geometric art was more developed, with the spirit of the inscription, than visual - figurative contents. According to King (1985) ,...in the non-figurative repertoire, art in the Near East reserved 
major roles for inscriptions of a religious nature, for symbolic devices and...for crosses, with the rest of the subsidiary areas filled by geometric and foliage motifs" (p. 276). Such artistic practices constituted a fertile ground and, after the arrival of Islam, affirmed the written word as an artistic expression as in the case of Islamic calligraphy. Therefore, the Islamic calligraphy started to be viewed as the most dignified way for the transmission and worship of God's words (El-Faruki, 1989, p. 19). Actually, this is the most perfect way of how to get closer to God, Who is transcendental, by reciting, writing or transmitting His words. Such forms of artistic expression became, sacred, religious, or even secular, where presented in the mosques, sacred palaces, public buildings and homes. Although calligraphy in Islamic art replaced the entire repertoire of paintings and sculptures couldn't become its mere substitute. With the exception of architecture, calligraphy is the first art that was created under the umbrella of Islam, and was affirmed, in a sense, by the revelation. Thus due to the need for the collection and transmission of the revelation of God the calligraphy was created. The calligraphic art has remained true to its original need for more beautiful writing of God's revelation. Nevertheless, it was released from the format of the book and became an independent art form, which has branched out into all fields and all media, from the calligraphic inscriptions as independent works, then architecture, in which it experienced monumental editions, and through usable objects in everyday life, and so entered, in the secular sphere of life as well.

The Islamic calligraphy was not only emphasizing copying of the sacred and holy texts. There are early inscriptions of specific people who in the Islamic tradition represent the Islamic spirituality. There are the names of Prophet Muhammad (pbuh) then four of the Caliphs, names of Prophet's grandsons Hassan and Husayyin and, as well as, the name of the first muadhin Bilali Habashi. These calligraphic inscriptions, in addition to certain Qur'anic verses, are often placed on the walls in the mosques (Elwazani, pp. 478-495). However, calligraphic writing of the names did not stop with those honorable names, but throughout the history of Islam there appear other honorable names that represented the pillars of spirituality of their time. They were, actually, considered as an extension and continuation of the spirituality. Therefore, very often calligraphic art represents great Sufis. Of course, calligraphic works with this content are exclusively related to the Sufi gathering places, tekke and turbe. 
Here arises a question that deserves thorough analysis whether the calligraphic art of Islam can be interpreted as a kind of Islamic religious painting? Similarly, the other great civilizations and their letters were also associated with the sacred and creative. In that sense, letter is considered a sacred science. For example, sacred art in Buddhism focuses on writing as a spiritual art form, "a technique of painting in ink characters - calligraphy, which is associated with the spiritual method dhyana (contemplation)" (Burckhardt, 2007, p. 174). Then according to Oto Bihalji-Merin, (1979) writing and painting are not separate skills. Alternatively, Egyptian art image letters - ideograms, as irreplaceable part of artistic expression, were considered as sacred curves. The other letters also experienced various creative formations, but it seems that no other letter can develop to the extent of becoming the leading artistic discipline of a great civilization and art, as is the case in Islamic art. Thus in that way a special kind of calligraphic art of Arabic letters, incorporating figurative motifs or vision, developed without significantly violating the basic postulates and the principles of Islamic art.

\section{Figural Representation of Arabic Calligraphy}

Calligrams or figural calligraphy is most often connected to the Turkish art of the 16th century. Within this artistic corpus, an art that to some extent identifies with tariqats (Sufi Orders) is plunged into a folk art. Calligrams generally can be found in the Sufi circles. Although similar works can be found in Shi'i circles of Persian art, from where an impact for creation and popularization of this style of calligraphy could be traced. Sufi circles for the most part, consisted of artists from different domains, so that a large number of them practiced the art of calligraphy (Schimmel, 1992, pp. 242-53 and Ben-Zaken, 2004, pp. 1-28). Besides other Sufi orders, the largest contribution to the arts had been given by Mawlawis and Baqtashis (Aksel, 2010, p. xvi). The art of calligraphy was interpreted as "spiritual mathematics materialized and developed by application of calligraphic equipment" (Hadžimejlić, 2009, 12). Therefore, very often calligraphy amplifies the crystallization of spirit, a reflection of the artist's spiritual condition and purity of heart, with the condition that their handwriting becomes more and more sophisticated.

In Bosnia-Herzegovina such calligraphic works were crafted by local artists, calligraphers and amateurs. Unfortunately today they have been preserved in an extremely small number. Due to the historical, cultural and spiritual connections between Turkish and Bosnian tariqats local 
artists also began to favor the calligrams. Besides, in BosniaHerzegovina only few dervishes and shaikhs practiced this form of artistic and spiritual expression. However, they were often pursuing their own path of self-knowledge and insight which contributed towards the emergence of Bosnian original calligrams. The authors of calligraphic art are not always considered as artists in a real sense of the term. However, according to Sufi tradition in any sense a humble servant of God attempts to come closer to God through his calligraphic works. Those spiritual masters do not celebrate or highlight their own personality and their works were mostly unsigned. Regardless of the small number of discovered calligraphic works, this branch of calligraphic art played significant role among the Bosnian Muslims who had a sense of aesthetics, which was noticed and appreciated across the Ottoman Empire. Therefore, this appears that arts, especially or exclusively traditional, reaches its peak only when the spirituality of the people to whom this art belong also reach a certain cultural and spiritual level. This has been affirmed by rare examples of calligraphic works that have survived past heritage destructions, as in the case of the past Bosnian war (1992-1995).

The development of calligrams might be traced back to the earliest period of Islamic art, when floral motifs started to develop in calligraphy, which represented the first connection of abstract shapes of letters with material forms (Safadi, 1978, p. 12). Thus, the ending of certain letters assumed a leaf form, and later became more and more involved in the intricate network of plant motifs, which sometimes twisted zoomorphic motifs as well. Sometimes the calligraphic writing is totally lost in the intricacies of this ornamentation, and it is difficult to recognize the shapes of letters. Then, sometimes letter endings received human forms, where the figure was contained in a letter, which culminated in the calligraphic works that acquired figurative form, where the shapes of letters depicted figurative representation as a kind of calligraphic painting (Safadi, 1978, p. 158). Some of them include Ali's Camel, Boat Ament Billah, Solomon's Seal, Emblem of Love, Boat of Writing, prints in the shape of the mosque, a pitcher, human figures, lions, bird, a glass, paired Waw's (Aksel, 2010, p. xvi).

The flexibility of the Arabic letters has produced within the classical calligraphy the expression of figures and characters through writing because such expression didn't violate the doctrine of Unity. This kind of integration of letters and images, uses primarily sacred elements (the letter), although calligraphic work does not necessarily have to belong to 
the category of sacred art, but they usually have a religious character, depending on the subject of the inscriptions (Khatibi, 1996, p. 90). Painting with letters is the term associated with the writing of holy verses within materialized pattern of nature. Here, calligraphic mediums are not solely used, but there is use of classical painting methods as well. The most common motives of calligraphic lines are zoomorphic forms, human figures and figures, which become allowed motives because they are not the purpose themselves, but one part of a complex and organized composition (Figure 1). Therefore, calligraphy doesn't attempt to imitate the nature as the nature is not the measure of reality, and therefore calligraphy just tries to understand "transcendental" essence of nature as a subject matter. The calligraphic call is not "admire the material world," but admire the Almighty God. These calligraphic works were created under the influence of symbolism, which artists recognized in the material world. Therefore as a result of such relationship so-called pictorial calligraphy or calligramy was introduced in the Arabic arts.

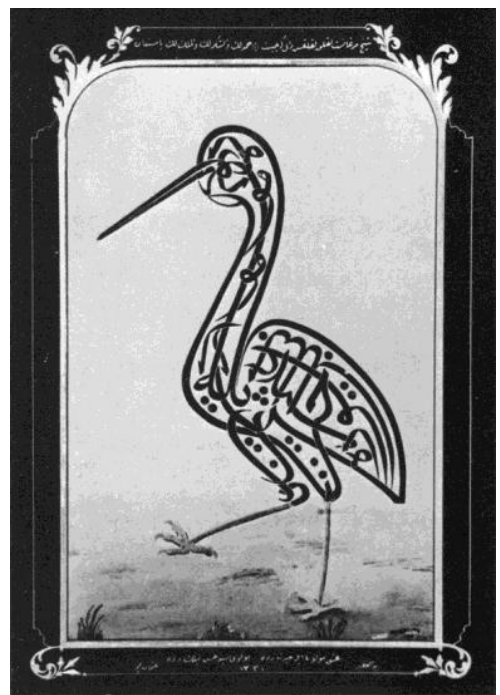

Figure 1. Calligraphic expression in the form of a bird by Leylek Dede (end of the 18th and the beggining of 19th century), Turkey. (from Șevket Rado, Türk Hattatlarl, Istanbul, Matbaacılık Ticaret Limited Ști., n.y., p. 206.)

Islamic art in general is the art of character, with symbolic meaning. In the Holy Qur'an the verse is a sign as in the following verse "We will show them evidence (signs) on our horizons and in themselves ... "(41:53). This reference is to the symbol, the second dimension that is hidden in all things, the attempt to search for signs in the external, visible and in the inner, hidden, apparently inspired the artists, who were able to 
use their insight to produce calligraphic works (Grabar, 1992, p. 87-88). Thus, calligrams make the relationship between the living beings, their metaphysical dimension and their Creator. Calligrams stimulate viewers to consider both metaphysical and physical dimensions of the reality.

One common example of calligrams that was found even in the mosque premises is Boat of Salvation (Teparić, 2013, p. 300. In calligrams of boats there are usually six printable postulates of faith - "Amantu billahi wa mala'ikatihi wa kutubihi wa rusulihi wa al-yaum al-akhiri wa al-qadri khayrihi wa sharrihi min Allah wa Ta'ala" - I belive in God, and in His angels, and in His books, and in His messengers, and in the Day of Jugment, I believe that whatever happens, happens with God's will and determination (Figure 2). It is significant to ask why the motive or symbol of boat was chosen. One possible explanation of this calligram could be linked with Noah's boat. Boat as a symbol of the salvation, as Noah's boat was purposefully made for those who believed in One God. Therefore, the boat in calligraphy, with six-art inscription of postulates of faith, represents a rescue boat, indicating six basic postulates of faith, which, if truly followed, can bring about the salvation for those who believe. Therefore, such calligrams primarily focus on the textual content but also with its visual expression they influence the observer's own belief.

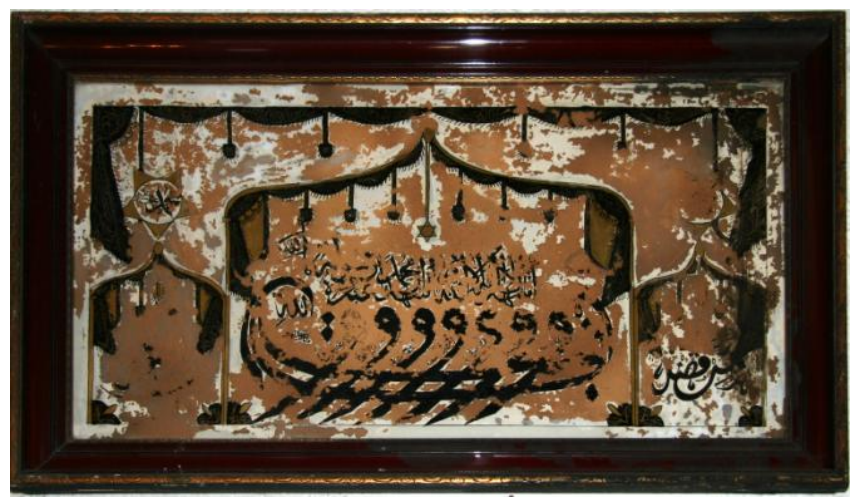

Figure 2. Caligraphic expression in the form of a boat by unknown author, Buzadži Mosque, Sarajevo

Calligrams in the form of stylish writing but at the same time in the form of an image find their places in the mosque. For instance, in Gazanferija Mosque in Banja Luka, two calligrams of a boat were placed at the entrance portal to the mosque and in the smaler mihrab on the sofas (photos, Husedžinović 440-441.) This kind of unification of writing and drawings of the sacred text with figurative forms and material forms is 
not prevalent in other cultures and civilizations. Calligrams, which are organizationally complex, also encourage speculation. They often inspire a search for the discovery of the hidden reality of the manifestations of artistic forms (Figure 3). This union of drawing and writing in their linear design hides, dissolves, and dematerialize, material frame, which in turn can be interpreted and understood as a message that there is only God's creation and that His dominion is over all creation. Basmallah is one of the most often written calligrams, but as calligraphic sentence as well. In figurative form Basmallah is perhaps the most commonly found in the form of birds (Grabar, 1992, p. 86). Dashed figural scenes are just a pale silhouettes or mold in which the lines of the letters move, twist, and writhe, stretch, and compress to suggest not only a printed message that has its clear meaning, but also another cloaked, hidden meaning and symbolism.

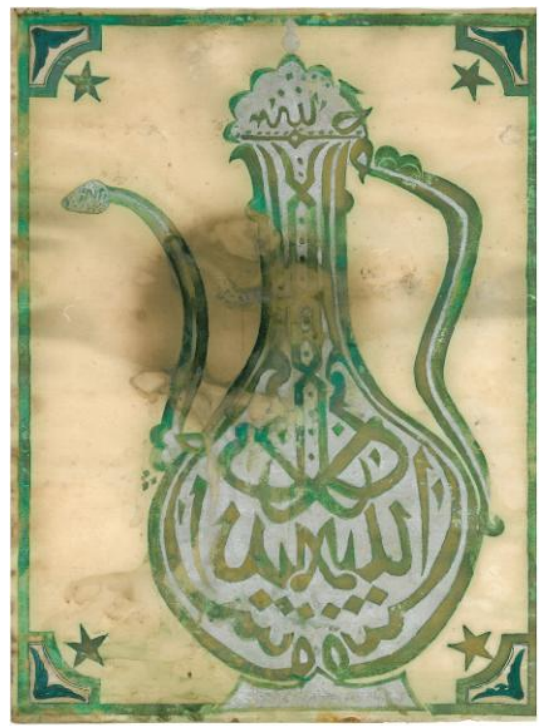

Figure 3. Calligraphy expression in the form of a jug, Family Museum Hadžimjelić, Živčići

The Arabic letters, written in the realistic and material framework, often decode certain forms within which various meanings are hidden (Grabar, 1992 , p. 101). Some of these motifs on calligraphic works, such as birds or lions actually represent symbols that are associated with individual personalities known for their spirituality, and within calligraphy, there is a text related to the calligrapher or his name. So calligraphically, the names of personalities are usually written in the intricate tangle of Arab letters. After their death dervish orders were established and strange 
mystical stories and events were associated with them. There were even such stories which narrate that great Sufis sometimes appeared in the same form. During their life, such calligraphic works were not manufactured. Only after their death, people out of an honor to their spirituality, righteousness and devotion printed those calligrams. One of these caligrams, which specifically enigmatically operate, is a calligraphic work of dove, within which lies an intricate writings "Oh, Hazrat Haci Bektaş"(Figure 4). "The calligraphy also refers to the tradition according to which Haci Bektaş appeard in the shape of a dove (DeJong, 1992, p. 234). They reveal themselves as one hidden secret, as an enigmatic mystery or mystical riddle that contains the answer in itself.



Figure 4. Calligraphic expression Bird (Haci Bektaş), by Muhamed Hadžimejlić (private collection)

This bird is a pigeon, which with its voice; pronounce $H u, H u$, therefore, makes dhikr which glorifies Allah, the Almighty. People who have seen in the birds a certain spiritual symbolism openly harbored respect for them. They are Allah's creatures, but they are nevertheless considered as one aspect, namely the depiction or symbol of angels understandable to the human mind, and accordingly they bring with them good things. Symbolically, the bird is the soul that yearns to be free of material bondage, to soar to the heights of eternal residence to the Ruler of birds 
or as the Sheikh Attar. The symbolism of birds has special significance since the beginning of humankind, from Adam. Raven taught Kabil how to bury his brother Abel whom he killed. Sulayman hung out with birds and spoke with them. Then in the Sufi texts bird as a symbol has a particular place and meaning, as pigeons that carry news. Anqa Mughrib a mystical bird or invisible bird is a reflection of the spiritual conditions. Therefore, it is a common feature in poetry as a paradigm unobtainable, something that is between heaven and earth (Aksel, 2010, p. 60).

There are many other similar calligraphic representations (Figure 5), in the form of drawings. All of them consist of the figurative concept, material form and, more importantly, the message. Then, drawing seemingly disappears before the reader or the viewer whereby multiple images appear, which symbolize multiple versions of the single reality (Khatibi, 2000, p. 214 and p. 219). Although the first visible form from the prints does not reveal the mystery and symbolism which has a composition, it is in this way just indicated. Here, the characters are twisted into a curved shape, and represents the forms of physicality. Actually, figure essentially does not exist but only the letters in a figurative concept, which does not compromise integrity and aesthetic beauty.

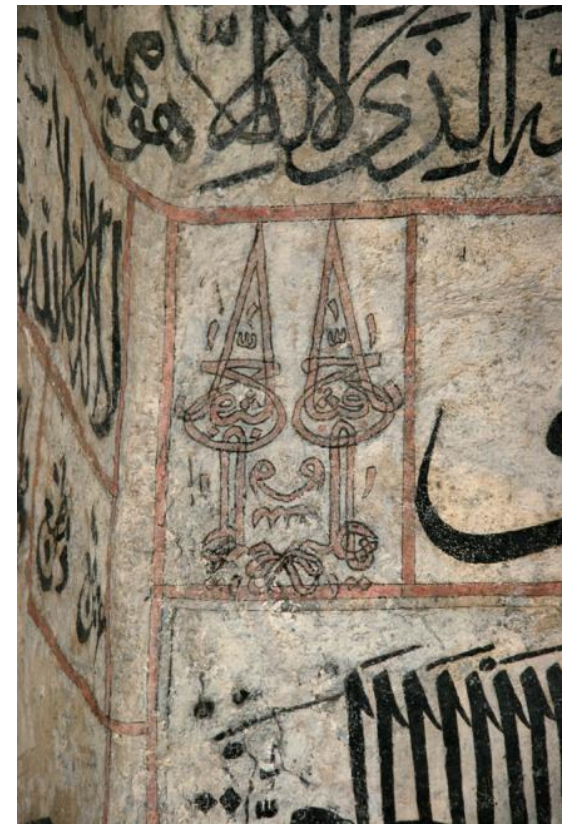

Figure 5. Wall calligraphic expression which resembles cypress, Sinan Tekke, Sarajevo 
The calligraphic letters are in the form of visual art instrumentation and figuration. Lines like the image make the content for "painting in words." Letters make distinctive figurative material shape, which is just borrowed form of a spoken word, and the letters are a medium from which shape is formed. This also shows the flexibility of Arabic letters to assimilate to each form, and that is what is recognizably in this material world. In addition, human beings identify themselves with the shapes of individual letters, whether in standing upright position or in the position of prayer. In this regard, letters used for such description are connected with the word "Al-hamd," which in Arabic language means to be thankful to God. But in the very structure of man, on his body parts and in his skeleton there are identifiable shapes of letters, and hence the calligraphic inscriptions that look like drawings of a faces, portraits or human figures that represent the perfect man or Insan-al-Kamil (DeJong, 1992, p. 234; Teparić, 2013, p. 301), (Figure 6). Al-Hamd is perceived through the basic movements in prayers: standing, prostration and sitting. Alif first letter of the Arabic alphabet is a symbol of the unity of Allah, in this pronouncement Al-hamd - thankfulness to Allah Almighty, also symbolizes a person in the prayer. Following is the the letter Lam, connected with other letters, symbolizes the prayer at qiyam. Letter $\mathrm{Ha}$ represents rukuu. Letter Mim symbolizes prostration, and letter Dal sitting position in the prayer (Teparić, 2011, pp. 90-91).

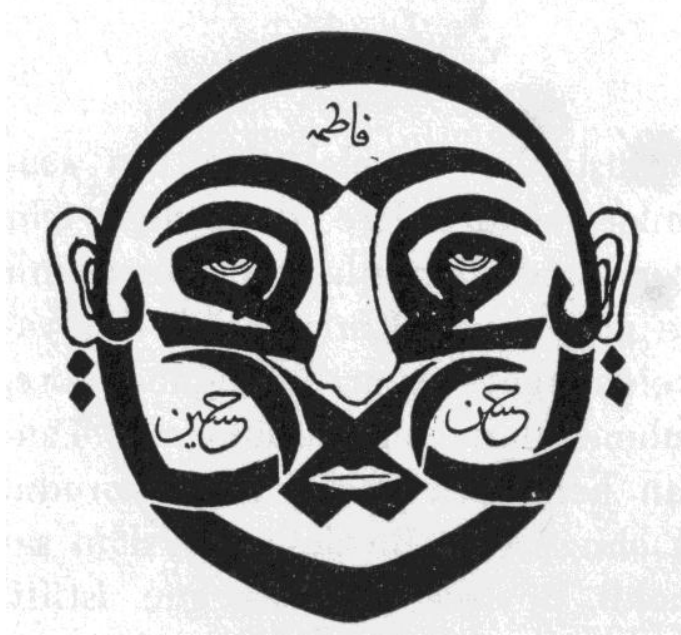

Figure 6. Calligraphic expression in the form of a portrait. (from Malik Aksel, Türklerde Dini Resimler, Istanbul, Kitap1, 2010, p.92.) 
Such calligraphy, with figurative character possesses multiple meanings: characters have their own symbolism, the message that carries the calligraphic text, and figurative form in which the letters appear. The essential meaning of calligraphic compositions is in the common correlation of these elements. Visually, the text is translated into a concept of an image. The text and image are presented as one against the other resembling the conception of a mirror (Avner, 2004, p. 17). However, they do not represent two separate entities but a symbolic meaning as a whole. The image itself, presentation of figure without text, would not possess anything but a common figure illusion, while on the other hand, written text without tangible form would not be wearing anything but a literal inscription. Another, completely different meaning is hidden behind these mutual correlations, one aesthetic, an enigmatic meaning that is on the higher symbolic-meaning level (Schimmel, 1992, p. 247). It can be said that the whole point of this relation depends on the interdependence of words and images.

Most of the Muslim artists were considering that this type of calligraphic expression, both visual and figurative contents, does not contradict the doctrine of their faith. Therefore, they connected the religious character of the art with the creative energy, while using the holy script and symbols of artistic content (Khatibi, 1996, p. 90). It seems that it was for that reason that the text of the image, which is associated with material figurative concept, emphasized the very mystique and sense of inscrutability of Arabic letters in the Arabic calligraphy. This approach certainly helps artists to understand that presenting characters is the human need because art is important tool for establishing the relationship between worshippers and God. Hence, with this phenomenal world through which human being experience God, the calligraphic art is able to integrate a transcendent character (DeJong, 1992, p.229). On the other hand, calligraphic art can be used to map the phenomenal and transcendental worlds that in mysterious ways surround man.

One among many unusual shapes of calligrams that are not in the shape of ship or bird is the calligram in the shape of a hat. The question might be posed; why they are in a form of a hat? Motif of a hat or taj, is a symbol of spirituality, spiritual teacher, conductor - Shaikh, a person who has acquired knowledge of himself and through it, God as well. Taj is usually drawn with the name of $\mathrm{Hz}$. Mevlana. In addition, very often there are in prints of Household of the Prophet, the Ahl-i Bayt, (Figure 7) which is especially respected in the Sufi circles, but also sentence 
expressing the unity of God, La ilaha ilallah (Hadzimejlic, 2011). As far as the symbol of a hat is concerned, it seems that in Islam a great attention is paid to head cover, both women and men, especially at the time of prayer. Taj is a very important symbol of tariqats, dervish's ranks, (Laqueur, 1992, p. 284). In general, throughout the history, the hat was an indicator of a status, profession and spiritual hierarchy. It is no coincidence that symbol of a hat had been chosen to be the hallmark of the tombstones for Muslims. In tariqahs, hat represents holiness, not all were privileged to wear the taj, only those who possessed sacred knowledge, knowledge of God, are worthy of wearing it and only at religious ceremonies (Atasoy, 1992, p. 266). Therefore, in Islam hat is not a matter of fashion. In the Sufi Order, there is certain difference in the tajs, which is associated with their founders, certain holders of tariqats by whom the tariqat is named. They usually wore certain symbols, characteristic for the same tariqats.

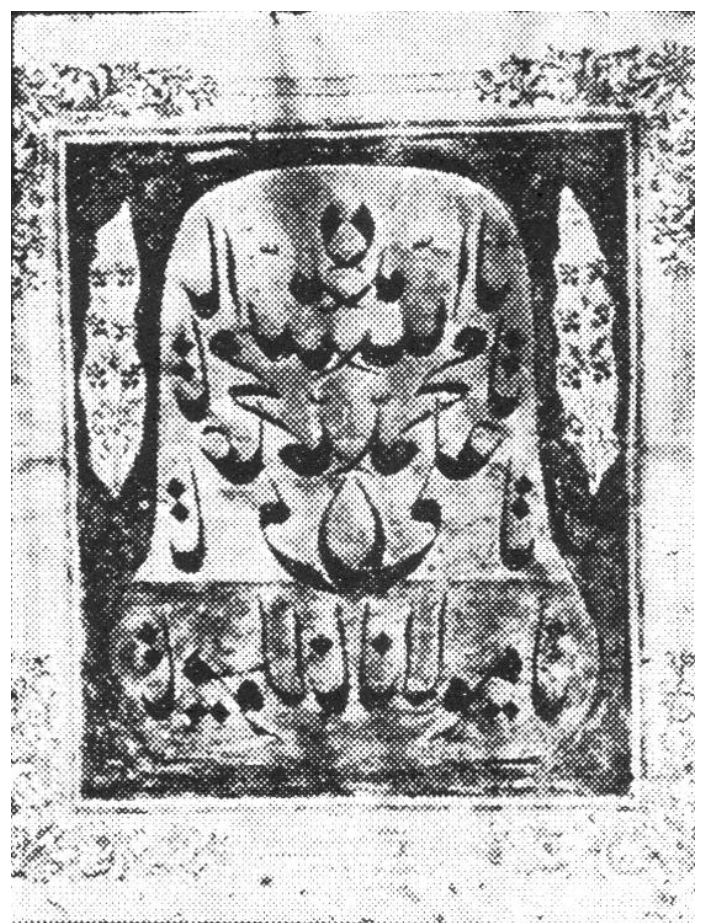

Figure 7. Calligraphic expression in the form of a taj, Bosnian calligrapher Muhammad Naqshibandy19. c. (Mujezinović, 1991, p. 466).

Symbols on tajs' are often considered as sacred codes that are not known to the wider public. Taj thus, represents a link with the Pir of tariqats. 
Therefore, it is considered that the Taj, a symbol of connection with evlijas - holy people, and that these symbols pass certain energy. Eventually taj means striving for a "mystical" unification with the Lord. Therefore, little form of the Taj by its shape resembles the Arab letter M Mim, which refers to Muhammad (pbuh), (Schimmel, 1970, p. 13). Only those who are capable to carry his taç could establish the branches of spirituality that spring from Muhammad (pbuh). According to some interpretations, the whole world, the universe, all creation is under God's hat, taj, hence it is interpreted as a liaison with mystical unity with the Lord. For Sufis and dervishes, out of respect and loyalty hat is kissed when placed or removed from the head. It is known that mevleije were buried with the hat, called sikke. Calligraphy in the taj shapes, as the invocation of the presence or association with Pirs, has been exclusively related to the Tekke and turbets of their members (Tanman, 1992, p. 142).

\section{References}

Aksel, Malik. 2010. Türklerde Dini Resimler. Istanbul: Kitap1.

Atasoy, Nurhan. 1992. „Dervish Dress and Ritual.“ In Raymond Lifchez. (Ed.) Architecture, Art and Sufism in Ottoman Turkey. California: University of California Press. pp. 253-268.

Ben-Zaken Avner. 2004. "The Heavens of the Sky and the Heavens of the Heart: The Ottoman Cultural Context for the Introduction of Post-Copernican Astronomy." The British Journal for the History of Science. Vol. 37, No. 1, pp. 1-28.

Bihalji-Merin, Oto. 1979. Re-vizija umetnosti. Beograd: Jugoslovenska revija.

Burckhardt, Titus. 2007. Sveta umjetnost na Istoku i Zapadu. Sarajevo: Tughra.

Buckhardt Titus. 2007. Alhemija. Sarajevo: Lingua Patria.

DeJong, Frederic, 1992. "Pictoral Art of the Bektashi Order." In: Raymond Lifchez. (Ed.) The Dervish Lodge: Architecture, Art, and Sufism in Ottoman Turkey. California: Universty of California Press, pp. 228-241.

Elwazani, Salim A. „Sacral Qualities of Form in Mosque Architecture.“ The American Journal of Islamic Social Scinece, Vol. 12, No. 4, pp. 478-495.

El-Faruki, Ismail Radži, 1989. „Tevhid: Princip estetike.“ Islamska misao. Sarajevo, No: 132, pp. 13-20.

Grabar, Oleg. 2003. "The Story of Portraits of the Prophet Muhammad." Studia Islamica. No. 96. pp.19-38. 
Grabar Oleg. 1992. The Meditation of Ornament. New Jersey: Princeton University Press.

Hadzimejlic Ćazim. 2011. Umjetnost islamske kaligrafije. Sarajevo: Sedam.

Hadzimejlic Ćazim. 2011. Katalog: Estetika pera. Sarajevo.

Khatibi, Abdelkebir \& Sijelmassi, Mohamed. 1996. The Splendour of Islamic Calligraphy. New York: Tames \& Hudson.

King G. R. D. 1985. "Islam Iconoclasam, and Declaration of Doctrine." Bulletin of the School of Oriental and African Studies. Vol. 48, No. 2, pp. 267-277.

Laqueur, Dans-Peter. 1992. "Dervish Gravestones." In Raymond Lifchez, (Ed.) The Dervish Lodge: Architecture, Art, and Sufism in Ottoman Turkey. California: Universty of California Press. pp. 284-295.

Mehinagic, Ibrahim. 1973. "Slike božjih poslanika i veoma čudne priče o njima.” Takvim. pp. 27-36.

Mujezinović, Mehmed, 1991. Islamska epigrafika Bosne i Hercegovine. Sarajevo: Sarajevo Publishing.

Nasr, Seyyed Hossein. 2005. Islamska umjetnost i duhovnost. Sarajevo: Lingua Patria.

Nasr, Seyyed Hossein. 2006. "Religious Art, Traditional Art, Sacred Art." In The Essential Sophia, (ed. Seyyed Hossein Nasr \& Khaterine O'Brein), World Wisdom, inc., pp.175-185.

Rado, Șevket. (n.y.) Türk Hattatları. Istanbul: Matbaacılık Ticaret Limited Ști.

Safadi, Yasin Hamid. 1978. Islamic Calligraphy. London: Thames and Hudson.

Schimmel, Annemarie. 1992. "Calligraphy and Sufism in Ottoman Turkey." In Raymond Lifchez. (Ed.) The Dervish Lodge: Architecture, Art, and Sufism in Ottoman Turkey. California: University of California Press, pp. 242-252.

Schimmel, Annemarie. 1970. Islamic Calligraphy. Leiden: Brill.

Tanman, M. Baha, 1992. "Settings for the Veneration of Saints." In Raymond Lifchez, (Ed.) The Dervish Lodge: Architecture, Art, and Sufism in Ottoman Turkey. California: Universty of California Press, pp.130-147.

Teparić, Meliha. 2011. "Namaz, harf i čovjek." In: Kelamu'l Shifa, VII, No. 28-29.

Teparić, Meliha. 2013. "Islamic Calligraphy and Visions." Ikon - Jurnal of Iconographic Studies, Vol. 6, pp. 297-306. 